\title{
Key Performance Indicators On Supply Chain Performance Measurement In An Electronic Commerce: A Literature Review
}

\author{
Wahyu Oktri Widyarto, Mohamad Jihan Shofa, Nugraheni Djamal
}

\begin{abstract}
Based on the information and communication technology revolution are characterized by Internet usage in various fields, the business environment also does changing by applying the concept of Electronic Commerce (e-commerce) on its process. Like business activities in general, e-commerce also requires the involvement of various parties, which are referred to Supply Chain Management (SCM). The challenge is while the Supply Chain (SC) performance measurement, that generally conducted in the company with non e-commerce, applied on ecommerce business process. Otherwise, only a few literature studies discuss partially dimension of performance measurement in e-commerce. Therefore, it is important to conduct a literature study about key performance indicators (KPIs) for measuring SC performance in e-commerce dimensions, and it would be explained in this paper. The contribution of this paper proposed the KPIs' that could be used for measuring SC performance in an e-commerce business process in order to be a new approach on the development of SC performance measurement models.
\end{abstract}

Index Terms: e-commerce, KPIs, literature review, SC performance measurement.

\section{INTRODUCTION}

Along with the rapid development of information technology, one of which is marked by the utilization of the internet in various fields, the business world has also made a change by applying the e-commerce concept to its business processes. As conveyed by [1]-[3], that web and the Internet have an effect on the company in building its business. The rapid development and use of the Internet and the web have brought about the concept of e-commerce marketing where transactions between consumers and companies are done virtually [4], [5]. Many companies adopt the e-commerce concept in the face of global competition [3].

The importance of the role of all parties from suppliers, manufacturers, distributors, retailers, and customers in creating cheap, quality, and fast products is what creates a new concept of Supply Chain Management (SCM) [6]. SCM consists of all parties involved directly or indirectly in meeting the consumer's wishes [7]. As with business activities in general, business activities with e-commerce also require the involvement of various parties. Reference

Revised Manuscript Received on April 19, 2019.

Wahyu Oktri Widyarto, Industrial Engineering Department, Universitas Serang Raya, Serang, Banten, Indonesia.

Mohamad Jihan Shofa, Industrial Engineering Department, Universitas Serang Raya, Serang, Banten, Indonesia.

Nugraheni DJamal, Industrial Engineering Department, Universitas Serang Raya, Serang, Banten, Indonesia.
[4] states that effective and efficient SCM is essential to support the success of companies involved in e-commerce.

As a basic information to determine the supply-chain performance, the supply chain performance measurement needs to be done considering the presence of various parties in the supply chain network [8]-[11]. The existence of supply chain performance measurement enables the supply chain to manage strategically and continuously to achieve its goals [12]. Measurement of supply chain performance can be the basis of control, communication and company strategy to improve operational [13].

Measurement of supply chain performance needs some performance indicators called Key Performance Indicators (KPIs) [14]. Determination of KPI on measurement of supply chain performance needs to be tailored to company goals. The challenge faced in measuring supply chain performance is determining KPIs based on company strategy goals, determining how to measure and determining how to implement them [15]. Related to that, it is necessary to identify the KPI used for measuring supply chain performance in e-commerce. The discussion on the measurement of supply chain performance has been done. The challenge is while the Supply Chain (SC) performance measurement, that generally conducted in the company with non e-commerce, applied on e-commerce business process. Otherwise, only a few literature studies discuss partially dimension of performance measurement in e-commerce. References [13], carried out a performance measurement on the food supply chain. References [16], determines the KPI to evaluate the implementation of Radio Frequency Identifier (RFID) as a technology application in SCM. Ecommerce performance measurement in terms of logistics is carried out by [4]. E-commerce performance measurement reviewed from aspects of information systems by [2]. References [17], identified performance indicators to measure supply chain performance on e-commerce based on logistics capabilities. References [15], states that performance measurement is very important in managing a supply chain effectively, especially in e-commerce and virtual enterprise. Therefore, it is prominent to identify KPIs from various aspects for measuring supply chain performance in e-commerce, and that will be discussed in this paper through literature study. The contribution that can 
be given from this paper is KPI's proposals from various aspects that can be used for measuring supply chain performance in e-commerce business processes that are expected to be a new approach in the development of the supply chain performance measurement model.

\section{LITERATURE REVIEW}

\section{A. Measurement Of Supply Chain Performance}

Performance management and continuous improvement are an important aspect of SCM. There is a need for a measurement system that can be the basis of overall SC performance evaluation [18]. Performance measurement can be defined as an act of measuring an effectiveness and efficiency of a process [11], [15], [19]. Reference [20] states that performance measurements are performed to measure the effectiveness of the strategies used in the supply chain and to identify opportunities in the future. Improved supply chain performance is an ongoing process that requires two aspects of analytical performance measurement system and mechanisms to achieve KPI goals [21]. Measurement of supply chain performance can be a facilitator for mutual understanding and integrating supply chain members [22].

The purpose of performance measurement in SCM is to obtain information on activities that are not in line with the objectives and to determine the plan of action that can be done. The main advantage of the supply chain performance measurement system is to provide a framework for information on business performance [8]. Many metrics are used in supply chain performance evaluations designed to measure operational performance, evaluate effectiveness levels and test overall SCM strategies [21]. While [14], states that the measurement of supply chain performance can be done with various approaches, techniques, criteria and metrics based on the supply chain strategy.

Reference [7], using the Supply Chain Operation Reference (SCOR) model in measuring supply chain performance by applying a process-based approach. Supply chain performance can be categorized into five supply chain processes: plan, source, make, deliver and return or customer satisfaction that will measure cost, time, flexibility and innovative quality, also qualitative and quantitative measures [23], [24]. Performance measurement based on cost and non-cost perspective, strategy perspective, tactical, and operational focus has been studied by [25]. Based on the system approach, [14], categorizes the supply chain performance measurement into perspective approaches, process approaches, and hierarchical approaches. Measurement of supply chain performance in an individual usually uses four categories: quality, time, cost and level of flexibility [21].

\section{B. Electronic Commerce (E-Commerce)}

E-commerce is the use of inter-network computers to create and modify business relationships. E-commerce is also expected to provide a simpler and more efficient way to complete business transactions [1]. In general, business transactions occur between sales and purchase of information, products, and services via the internet [1], [5], [26]. While according to [2], e-commerce is the use of the internet to facilitate, process, and carry out business

transactions. E-Commerce requires a new logistics approach. Generally, logistic activities take place are small order sizes, increased volume of daily orders, small packet delivery, and day delivery. However, to ship goods to the front door of the customer on time is a complex task. The success of the company in e-commerce depends on the efficiency of the company's distribution network [4]. Ecommerce can impact on marketing, customer service, and supply chain efficiency. This is because e-commerce can open new markets, lower costs, and more business competition. Therefore, e-commerce can make the company easy to understand consumer desires and can provide fast and accurate service to consumers. With the internet, ecommerce also enables companies to develop and enhance cooperation with suppliers [27].

E-commerce is a new phenomenon in the business and will be redefining the business world rapidly. To manage and make decisions in e-commerce, organizations or companies need to know the essential aspects of ecommerce architecture [28]. The e-commerce component consists of: [5]

1. Electronic Data Interchange (EDI), i.e the exchange of computer data between departments within the organization of a structured and computerized information.

2. Digital Currency, a facility that users can use to make their money electronically.

3. Electronic Catalogs, which is the main component of e-commerce that provides information on products and services offered.

4. Intranet, which is a collection of web sites owned by a group and accessible only by members of the group.

5. Extranet, which is a particular part of the intranet that can be accessed by a specific authorization by a party outside the intranet group member.

E-commerce develops in a variety of ways in business environments, including Business to Customer (B2C), Business to Business (B2B), Business in Business (BIB), and Customer to Customer (C2C). Generally, most ecommerce is formed by the B2B concept [29]. Technological innovation has led to the development of various theories associated with the diffusion of information technology and information systems [30].

\section{METHODOLOGY}

In this literature study, identification of performance measurement characteristics will be adjusted between the supply chain and e-commerce through research exploration. Reference [31] states that the purpose of conducting research expositions is to get the initial idea of a topic, to get the basis for detailed research development, to improve the technique of existing ones.

The methodology in the study of this literature is to collect scientific articles in journals and proceedings both national and international. The scientific articles collected are regarding the measurement of supply chain and ecommerce performance. Search keywords used are supply chain performance measurement, supply chain and e- 
commerce. The scholarly articles that have been acquired hereafter are grouped into a supply chain performance measurement group and e-commerce group. This grouping is done to facilitate the sorting of unsupported scientific articles to conduct literature studies on the measurement of supply chain performance on e-commerce. Whereas for scientific articles that are appropriate to the study will be reviewed to get the relevant theories to the topic of this study. Some matters are considered in selecting scientific articles such as title, abstracts, keywords, and topics (supply chain and e-commerce).

Identification of KPIs is carried out by reviewing scientific articles in which performance measurement on ecommerce is generally still tend to be done partially on different dimensions of each. From these sources or scientific articles, it is then compiled into a KPI proposal that can be used in the measurement of supply chain performance in e-commerce and is expected to be a new approach in the development of the supply chain performance measurement model.

\section{RESULT}

Based on literature studies that have been conducted, some literature has shown the results of e-commerce performance measurement with different indicators. In this paper, KPIs are identified from various measurement indicators. The literature study that produces KPI as a proposal in the development of the supply chain performance measurement model is shown on the table 1 .

Table1. Proposal of KPI Measurement of Supply Chain Performance On E-Commerce

\begin{tabular}{|c|c|c|}
\hline No & Indicator & References \\
\hline 1 & $\begin{array}{l}\text { Improvement in } \\
\text { profitability }\end{array}$ & $\begin{array}{l}{[1],[2],[27],} \\
{[32]-[38]}\end{array}$ \\
\hline 2 & Increase in sales & $\begin{array}{l}{[1]-[3],[26],} \\
{[27],[33]-[36],} \\
{[39]}\end{array}$ \\
\hline 3 & $\begin{array}{l}\text { Return on } \\
\text { investment }\end{array}$ & $\begin{array}{l}2],[32],[34], \\
{[36],[40],[41]}\end{array}$ \\
\hline 4 & $\begin{array}{l}\text { Reduction of } \\
\text { operational costs }\end{array}$ & $\begin{array}{l}{[1]-[3],[29],} \\
{[36],[41]}\end{array}$ \\
\hline 5 & $\begin{array}{l}\text { Pre-Sale } \\
\text { Customer service }\end{array}$ & $\begin{array}{l}{[1],[2],[4],[40],} \\
{[42]}\end{array}$ \\
\hline 6 & $\begin{array}{l}\text { After-sales } \\
\text { service }\end{array}$ & $\begin{array}{l}{[1],[2],[4],[32],} \\
{[40],[42]}\end{array}$ \\
\hline 7 & Delivery speed & $\begin{array}{l}{[1],[2],[4],[32],} \\
{[33],[39],[40],} \\
{[42]}\end{array}$ \\
\hline 8 & $\begin{array}{l}\text { Delivery } \\
\text { reliability }\end{array}$ & $\begin{array}{l}{[1],[2],[4],[33],} \\
{[39],[43],[44]}\end{array}$ \\
\hline 9 & $\begin{array}{l}\text { Responsive to } \\
\text { target market }\end{array}$ & $\begin{array}{l}{[1],[2],[4],[5],} \\
{[27],[37],[45]}\end{array}$ \\
\hline 10 & $\begin{array}{l}\text { Low distribution } \\
\text { costs }\end{array}$ & [4] \\
\hline 11 & $\begin{array}{l}\text { Inventory } \\
\text { management }\end{array}$ & $\begin{array}{l}{[1],[5],[27],} \\
{[40],[43],[44],} \\
{[46]}\end{array}$ \\
\hline 12 & Payment process & {$[1],[42]$} \\
\hline 13 & Order tracking & [1], [43], [44], \\
\hline
\end{tabular}

\begin{tabular}{|c|c|c|}
\hline & status & {$[46]$} \\
\hline 14 & $\begin{array}{l}\text { Ability to share } \\
\text { information with } \\
\text { suppliers and } \\
\text { partners }\end{array}$ & $\begin{array}{l}\text { [1], [2], [4], [26], } \\
{[33],[34],[38],} \\
{[40],[44],[47]-} \\
{[51]}\end{array}$ \\
\hline 15 & Booking system & {$[1],[4],[44],[52]$} \\
\hline 16 & $\begin{array}{l}\text { Infrastructure of } \\
\text { information } \\
\text { technology }\end{array}$ & $\begin{array}{l}\text { [1], [2], [3], [5], } \\
{[28],[34]-[39],} \\
{[41],[45],[46],} \\
{[52],[53]}\end{array}$ \\
\hline 17 & $\begin{array}{l}\text { Ease of use of } \\
\text { web site }\end{array}$ & $\begin{array}{l}11],[2],[26], \\
{[34],[36],[46],} \\
{[47],[52],[54]}\end{array}$ \\
\hline 18 & Web site design & $\begin{array}{l}{[1],[2],[4],[5],} \\
{[26],[34]-[36],} \\
{[41],[47],[51],} \\
{[52],[54]}\end{array}$ \\
\hline 19 & $\begin{array}{l}\text { Electronic Data } \\
\text { Interchange }\end{array}$ & $\begin{array}{l}{[32],[39],[46],} \\
{[47]}\end{array}$ \\
\hline 20 & Data Consistency & {$[4],[32],[38]$} \\
\hline 21 & $\begin{array}{l}\text { Human Resource } \\
\text { Skills on IT }\end{array}$ & $\begin{array}{l}\text { [3], [28], [30], } \\
{[34]-[37],[41],} \\
{[45],[52],[53]}\end{array}$ \\
\hline 22 & $\begin{array}{l}\text { Information } \\
\text { system security }\end{array}$ & $\begin{array}{l}\text { [2], [29], [34], } \\
{[36],[39],[42],} \\
{[46],[52]}\end{array}$ \\
\hline 23 & $\begin{array}{l}\text { Internet service } \\
\text { provider }\end{array}$ & $\begin{array}{l}\text { [1], [28], [37], } \\
{[39],[45],[47]}\end{array}$ \\
\hline 24 & $\begin{array}{l}\text { Information } \\
\text { technology } \\
\text { investment }\end{array}$ & {$[1],[3],[28],[30]$} \\
\hline 25 & $\begin{array}{l}\text { Ability to share } \\
\text { information with } \\
\text { internal parties }\end{array}$ & $\begin{array}{l}{[1],[4],[26],} \\
{[33],[34],[38],} \\
{[40],[44],[47]-} \\
{[50]}\end{array}$ \\
\hline
\end{tabular}

Measurement of supply chain performance is important in efforts to improve operational effectiveness. This is because the results of performance measurement can be considered in making plans and strategies of corrective actions, especially in e-commerce as a growing business concept in the business world in the face of the challenges of information technology development that is rapid and influential in the increasingly competitive business competition.

Based on the literature review, it can be shown that many factors can be a variable in the measurement of the supply chain performance on e-commerce. The KPIs identified in the literature review are the combination of various measurements indicating that performance measurements on e-commerce are likely to still be partial in each dimension. Therefore, development of the supply chain performance measurement concept in e-commerce is still needed, which integrates various dimensions of measurement.

Published By:

Blue Eyes Intelligence Engineering \& Sciences Publication 
Several matters can be recommended for further research are:

1. Conducting a validation of KPIs that have been proposed in measuring supply chain performance in ecommerce.

2. Conducting a wider and deeper exploration to develop a supply chain performance measurement KPI on ecommerce that can complement the identified KPIs.

3. Conducting a measurement of supply chain performance on e-commerce with various approaches such as SCOR, Analytical Hierarchy Process (AHP), and others.

4. Developing a supply chain performance measurement model on e-commerce with various dimensions of measurement.

\section{ACKNOWLEDGMENT}

This paper is part of a research supported by the Ministry of Research, Technology, and Higher Education (Kemenristekdikti). Therefore, the authors would like to express their gratitude to Kemenristekdikti for full support in research funding through the Basic Research Grant of Higher Education scheme for the implementation year 2019. The authors are grateful to reviewers for their constructive suggestions.

\section{REFERENCES}

1. B. Chan and S. Al-Hawamdeh, "The Development Of ECommerce In Singapore: The Impact Of Government Initiatives," Business Process Management Journal, vol. 8, no. 3, pp. 278-288, 2002.

2. W. H. DeLone and E. R. McLean, "Measuring eCommerce Success: Applying the DeLone \& McLean Information Systems Success Model," International Journal of Electronic Commerce, vol. 9, no. 1, pp. 31-47, 2004.

3. J. L. Gibbs and K. L. Kraemer, "A Cross-Country Investigation Of The Determinants Of Scope Of ECommerce Use: An Institutional Approach," Electronic Markets, vol. 14, no. 2, pp. 124-137, 2004.

4. J. Joong-Kun Cho, J. Ozment, and H. Sink, "Logistics Capability, Logistics Outsourcing And Firm Performance In An E-Commerce Market," International Journal of Physical Distribution \& Logistics Management, vol. 38, no. 5, pp. 336-359, 2008.

5. I. G. M. Karmawan, "Dampak Peningkatan Kepuasan Pelanggan dalam Proses Bisnis E-Commerce pada Perusahaan Amazon. com," ComTech: Computer, Mathematics and Engineering Applications, vol. 5, no. 2, pp. 748-762, 2014.

6. I. N. Pujawan and E. R. Mahendrawathi, "Supply Chain Management Edisi Kedua," Surabaya: Guna Widya, 2010.

7. N. M. Agrawal, "Performance Measurement With Changing Business Environment," Proceedings of IRF International Conference, pp. 40-50, 2014.

8. T. B. de Sousa, C. E. S. Camparotti, K. F. Esposto, and F. M. Guerrini, "Alignment of Balanced Scorecard Perspectives With Supply Chain Management Objectives: a Literature Review," Independent Journal of Management \& Production, vol. 5, no. 4, pp. 1050-1070, 2014.

9. E. Kusrini, N. A. Subagyo, and N. A. Masruroh, "A New Approach To Design Supply Chain Key Performance Indicator For Actors And Regulator: A Case Study In Innovative Product In Indonesia," International Journal of Business Performance Management, vol. 17, no. 1, pp. $1-29,2016$

10. A. Ridwan and S. Murni, "Pengukuran Kinerja Supply Chain Dengan Pendekatan Lean Six Sigma Supply Chain Management (Studi kasus di PT ALX Logistics)," Journal Industrial Servicess, vol. 3, no. 1, pp. 59-67, 2017.

11. H. Kazemkhanlou and H. Ahadi, "Study of Performance Measurement Practices in Supply Chain Management," International Conference on Industrial Engineering and Operations Management, no. Jan 7-9, pp. 273-285, 2014.

12. N. Agami, M. Saleh, and M. Rasmy, "Supply Chain Performance Measurement Approaches: Review and Classification," The Journal of Organizational Management Studies, vol. 2012, pp. 1-20, 2012.

13. B. Bigliardi and E. Bottani, "Performance Measurement In The Food Supply Chain: A Balanced Scorecard Approach," Facilities, vol. 28, no. 5-6, pp. 249-260, 2010.

14. H. Balfaqih, Z. M. Nopiah, N. Saibani, and M. T. AlNory, "Review Of Supply Chain Performance Measurement Systems: 1998-2015," Computers in Industry, vol. 82, pp. 135-150, 2016

15. A. Gunasekaran and B. Kobu, "Performance Measures And Metrics In Logistics And Supply Chain Management: A Review Of Recent Literature (19952004) For Research And Applications," International Journal of Production Research, vol. 45, no. 12, pp. 2819-2840, 2007.

16. Y. Bendavid, É. Lefebvre, L. A. Lefebvre, and S. FossoWamba, "Key Performance Indicators For The Evaluation Of RFID-Enabled B-to-B E-Commerce Applications: The Case Of A Five-Layer Supply Chain," Information Systems and e-Business Management, vol. 7, no. 1, pp. 1-20, 2009

17. W. O. Widyarto, M. J. Shofa, and N. Djamal, "Identification Of Performance Indicators Base On Logistic Capability For Supply Chain Performance Measurement In E-Commerce," Asia Proceedings of Social Sciences, vol. 4, no. 2, pp. 53-56, 2019.

18. I. N. Pujawan and E. R. Mahendrawathi, Supply Chain Management (Edisi Ketiga). Yogyakarta: Andi, 2017.

19. D. K. K. R, G. S. Shivashankar, and R. S. Kadadevarmath, "Impact on Manufacturing Process Through Effective Supply Chain Performance Measurement Approaches," vol. 1, no. 2, pp. 118-123, 2014.

20. E. Kusrini, Subagyo, and N. A. Masruroh, "Good Criteria For Supply Chain Performance Measurement," International Journal of Engineering Business Management, vol. 6, no. 1, pp. 1-7, 2014.

21. J. Cai, X. Liu, Z. Xiao, and J. Liu, "Improving Supply Chain Performance Management: A Systematic Approach To Analyzing Iterative KPI Accomplishment," Decision Support Systems, vol. 46, no. 2, pp. 512-521, 2009.

22. A. Khare, A. Saxsena, and P. Teewari, "Supply Chain Performance Measures For Gaining Competitive Advantage: A Review," Journal of Management and Strategy, vol. 3, no. 2, pp. 25-32, 2012.

23. C. Shepherd and H. Günter, "Measuring Supply Chain Performance: Current Research And Future Directions," International Journal of Productivity and Performance Management, vol. 22, no. 1, pp. 242-258, 2006.

24. F. T. Chan, "Performance Measurement in a Supply Chain," The international journal of advanced manufacturing technology, vol. 21 , no. 7 , pp. 534-548, 2003. 
25. A. Gunasekaran, C. Patel, and E. Tirtiroglu, Performance Measures And Metrics In A Supply Chain Environment, vol. 21 , no. $1 / 2.2001$.

26. F. R. Kodong, Juwairiah, and O. S. Simanjuntak, "Manajemen Rantai Pasokan Pada E-Commerce Industri Makanan Ringan KWT An-Naba Yogyakarta," Paper presented at the Seminar Nasional Informatika (SEMNASIF), pp. 139-146, 2015.

27. J. Huang, X. Jiang, and Q. Tang, "An E-Commerce Performance Assessment Model: Its Development And An Initial Test On E-Commerce Applications In The Retail Sector Of China," Information and Management, vol. 46, no. 2, pp. 100-108, 2009.

28. R. Javalgi and R. Ramsey, "Strategic Issues Of ECommerce As An Alternative Global Distribution System," International Marketing Review, vol. 18, no. 4, pp. 376-391, 2001.

29. N. Mansor and A. F. A. Abidin, "The Application of ECommerce Among Malaysian Small Medium Enterprises," European Journal of Scientific Research, vol. 41, no. 4, pp. 591-605, 2010.

30. M. I. Salwani, G. Marthandan, M. D. Norzaidi, and S. C. Chong, "E-Commerce Usage And Business Performance In The Malaysian Tourism Sector: Empirical Analysis,' Information Management and Computer Security, vol. 17, no. 2, pp. 166-185, 2009.

31. C. Forza, "Survey Research In Operations Management: A Process-Based Perspective," International Journal of Operations and Production Management, vol. 22, no. 2, pp. 152-194, 2002.

32. J. Hyvönen, "Strategy, Performance Measurement Techniques And Information Technology Of The Firm And Their Links To Organizational Performance," Management Accounting Research, vol. 18, no. 3, pp. 343-366, 2007.

33. D. Ariani and B. M. Dwiyanto, "Analisis Pengaruh Supply Chain Management Terhadap Kinerja Perusahaan (Studi Kasus Pada Industri Kecil dan Mengenah Makanan Olahan Khas Padang SUmatera Barat)," Dipenegoro Journal Of Management, vol. 2, no. 3, pp. 110, 2013.

34. W. G. Bremser and Q. B. Chung, "A Framework For Performance Measurement In The E-Business Environment," Electronic Commerce Research and Applications, vol. 4, no. 4, pp. 395-412, 2005.

35. J. Jauhari, "Upaya Pengembangan Usaha Kecil Dan Menengah (UKM) Dengan Memanfaatkan ECommerce," Jurnal Sistem Informasi, vol. 2, no. 1, pp. 159-168, 2014.

36. H. C. Looi, "E-Commerce Adoption in Brunei Darussalam: A Quantitative Analysis of Factors Influencing Its Adoption," Communications of the Association For Information Systems, vol. 15, 2018.

37. A. Ordanini and G. Rubera, "How Does The Application Of An IT Service Innovation Affect Firm Performance? A Theoretical Framework And Empirical Analysis On Ecommerce," Information and Management, vol. 47, no. 1, pp. 60-67, 2010.

38. A. Rai, R. Patnayakuni, and N. Seth, "Firm Performance Impacts Of Digitally Enabled Supply Chain Integration Capabilities," Managerial MIS Quarterly, vol. 30, no. 2, pp. 225-246, 2006.

39. J. Gibbs, K. L. Kraemer, and J. Dedrick, "Environment And Policy Factors Shaping Global E-Commerce Diffusion: A Cross-Country Comparison," The Information Society, vol. 19, no. 1, pp. 5-18, 2003.

40. B. Sezen, "Relative Effects Of Design, Integration And Information Sharing On Supply Chain Performance," Supply Chain Management: An International Journal, vol. 13, no. 3, pp. 233-240, 2008.
41. M. R. Wade and S. Nevo, "Development And Validation Of A Perceptual Instrument To Measure E-Commerce Performance," International Journal of Electronic Commerce, vol. 10, no. 2, pp. 123-146, 2005.

42. R. Ramanathan, "The Moderating Roles Of Risk And Efficiency On The Relationship Between Logistics Performance And Customer Loyalty In E-Commerce," Transportation Research Part E: Logistics and Transportation Review, vol. 46, no. 6, pp. 950-962, 2010.

43. A. M. Yaqoub, "Pengaruh Mediasi Kepercayaan Pada Hubungan Natara Kolaborasi Supply Chain Dan Kinerja Operasi," Jurnal Manajemen Dan Kewirausahaan, vol. 14, no. 2, pp. 138-146, 2012.

44. C. W. Lee, I. W. G. Kwon, and D. Severance, "Relationship Between Supply Chain Performance And Degree Of Linkage Among Supplier, Internal Integration, And Customer," Supply Chain Management: An International Journal, vol. 12, no. 6, pp. 444-452, 2007.

45. R. Evans, "E-commerce, Competitiveness and Local and Regional Governance in Greater Manchester and Merseyside: A Preliminary Assessment," Urban Studies, vol. 39, no. 5-6, pp. 947-975, 2002.

46. K. Zhu and K. L. Kraemer, "E-commerce Metrics For Net-Enhanced Organizations: Assessing The Value Of ECommerce To Firm Performance In The Manufacturing Sector," Information Systems Research, vol. 13, no. 3, pp. $275-295,2002$

47. J. Jeffcoate, "Best Practice In SME Adoption Of ECommerce," Benchmarking: An International Journal, vol. 9, no. 2, pp. 122-132, 2002.

48. V. R. Kannan and K. C. Tan, "Just In Time, Total Quality Management, And Supply Chain Management: Understanding Their Linkages And Impact On Business Performance," Omega, vol. 33, no. 2, pp. 153-162, 2005.

49. N. Mandasari and Widiartanto, "Pengaruh Information Sharing, Knowledge Sharing Dan Relation Terhadap Performance Perusahaan (Studi Kasus Pada Usaha Kecil Menengah Mebel Di Kecamatan Tahunan Kabupaten Jepara)," Prosiding Seminar Nasional ASBIS Politeknik Negeri Banjarmasin, 2016.

50. T. P. Stank, S. B. Keller, and P. J. Daugherty, "Supply Chain Collaboration And Logistical Service Performance," Journal of Business Logistics, vol. 22, no. 1, pp. 29-48, 2001

51. Risnandar and P. T. Wulandari W.K, "Integrasi Teknologi Informasi Dan Supply Chain Management (Studi Kasus : PT . X , West Java)," Seminar dan Call For Paper Munas Aptikom, pp. 267-273, 2010.

52. R. Ghamdi, A. Nguyen, and V. Jones, "A Study Of Influential Factors In The Adoption And Diffusion Of B2C E-Commerce," International Journal of Advanced Computer Science and Applications, vol. 4, no. 1, pp. 89-94, 2013.

53. A. Scupola, "SMEs' E-Commerce Adoption: Perspectives From Denmark and Australia," Journal of Enterprise Information Management, vol. 22, no. 1/2, pp. 152-166, 2009.

54. P. Palvia, "The Role Of Trust In E-Commerce Relational Exchange: A Unified Model," Information and Management, vol. 46, pp. 213-220, 2009. 